DOI: $10.14746 /$ por.2019.1.12

\title{
TRAGEDIA HOLOKAUSTU ORAZ ŻYDOWSKIE MIEJSCA PAMIĘCI NA UKRAINIE W POWIEŚCI J.S. FOERA WSZYSTKO JEST ILUMINACJA
}

\author{
MARTA SIEKIERSKA ${ }^{1}$ \\ (Uniwersytet im. Adama Mickiewicza w Poznaniu)
}

Słowa kluczowe: Jonathan Safran Foer, Holokaust, sztetl, trauma, pogranicze

Keywords: Jonathan Safran Foer, Holocaust, shtetl, trauma, borderland

\begin{abstract}
Abstrakt: Marta Siekierska, TRAGEDIA HOLOKAUSTU ORAZ ŻYDOWSKIE MIEJSCA PAMIĘCI NA UKRAINIE W POWIEŚCI J.S. FOERA WSZYSTKO JEST ILUMINACJA. „PORÓWNANIA” 1 (24), 2019. T. XXIV, S. 135-145. ISSN 1733-165X. Cel niniejszego artykułu stanowi próba analizy powieści, skoncentrowana na relacjach zachodzących między formą i językiem utworu a traumą historyczną, jakiej doświadczają bohaterowie. Specyficzna konstrukcja oraz język, który wykorzystuje w powieści autor, przekładają się na nowatorski sposób przetworzenia historii oraz tematu Zagłady. Tekst prezentuje również obecny w powieści pejzaż polsko-ukraińskiego pogranicza, wytyczanego przez historyczne, metafizyczne oraz kulturowe granice. Analizie i interpretacji zostaje poddana obecna w utworze bogata symbolika, uwypuklająca wymiar znaczącej nieobecności zgładzonej społeczności oraz wymownej luki, białego miejsca pamięci, która po nich pozostała.
\end{abstract}

\begin{abstract}
Marta Siekierska, THE HOLOCAUST TRAGEDY AND JEWISH SITES OF MEMORY IN UKRAINE IN THE NOVEL EVERYTHING IS ILLUMINATED BY J.S. FOER. "PORÓWNANIA" 1 (24), 2019. Vol. XXIV, P. 135-145. ISSN 1733-165X. The aim of this paper is to analyze the novel Everything is illuminated by Jonathan Safran Foer with consideration of the relation of the form and language to historical trauma experienced by the hero of this novel. The distinctive form and language employed by the author account for an innovative restatement of the history and the theme of extermination. The paper also addresses the landscape of the Ukrainian-Polish borderline, in Foer's work portrayed as one marked by historical, metaphysical and cultural borders. The subsequent object of analysis is the rich symbolism of Everything is illuminated which accentuates
\end{abstract}

1 E-mail: msiekierska@interia.pl 
the sense of meaningful absence, the blank space of memory that remains after the annihilation of the Jewish community.

Opublikowana w 2002 roku debiutancka powieść amerykańskiego pisarza żydowskiego pochodzenia, Jonathana Safrana Foera, Wszystko jest iluminacja (Everything is illuminated) w krótkim czasie zdobyła oszałamiającą popularność oraz uznanie krytyki. Utwór szybko stał się bestsellerem na rynku wydawniczym, zaś Foera część recenzentów przyrównywała do twórców pokroju Philipa Rotha (Sundberg, Gabe, źródło elektroniczne). Powieść wielokrotnie stanowiła przedmiot zainteresowania nie tylko krytyków literackich, ale również badaczy literatury. Ci ostatni najczęściej pochylali się nad kwestiami traumy Holocaustu, tożsamości etnicznej oraz nad mechanizmami przebaczenia i pojednania. Spektrum zagadnień poruszanych dotychczas przez badaczy w odniesieniu do tej powieści jest bardzo rozległe. Przykładowo Victoria Aarons oraz Alan L. Berger analizują narracje na temat pustki, braku tworzone przez przedstawicieli trzeciego pokolenia, którzy w odróżnieniu od pokolenia swoich rodziców, wychowanych w cieniu traumy, zmuszeni są do poszukiwań, podjęcia prób odtworzenia rodzinnych historii o Zagładzie, które wcześniej były marginalne $\mathrm{w}$ ich świadomości. Badacze analizują między innymi zagadnienia postpamięci, podwójnego wiązania między przymusem a zakazem mówienia czy problemów dotyczących trzeciopokoleniowych autorów, które znajdują wyraz w ich twórczości (Aarons, Berger, źródło elektroniczne). Z kolei Lisę Propst zajmują pytania o tożsamość oraz o możliwość pojednania wyrastającego na gruncie wspólnej spuścizny naznaczonej przemocą. W polu zainteresowań badaczki znajdują się również relacje żydowsko-ukraińskie, niejednoznaczna rola Ukraińców w zbrodniach popełnianych na ich żydowskich sąsiadach (Propst, źródło elektroniczne). Warto podkreślić, że to jedynie wybrane problemy badawcze spośród wielu publikacji poświęconych powieści. Jednakże wielbiciele dużego ekranu kojarzyć mogą film o tym samym tytule w reżyserii Lieva Schreibera, którego premiera miała miejsce w 2005 roku. Fabuła filmu zasadza się wokół karkołomnych poszukiwań prowadzonych przez młodego amerykańskiego Żyda, Jonathana Safrana Foera, przedstawiciela trzeciego pokolenia ocalonych z Zagłady, kobiety imieniem Augustina, mającej uratować jego dziadka z rąk nazistów w czasie wojny. W tym celu protagonista, owładnięty manią kolekcjonowania i dokumentowania rzeczywistości, wyrusza na odległy europejski kontynent, by na Ukrainie, w towarzystwie ukraińskiego tłumacza z przypadku oraz jego ekstrawaganckiego dziadka, przewodnika i kierowcy, odkryć prawdę o tamtych wydarzeniach. Tak w skrócie przedstawia się fabuła filmu. Jednak przytoczona powyżej w formie ilustracji historia stanowi zaledwie jeden z wątków powieści, której nie sposób scharakteryzować bez uprzedniego odnotowania wyjątkowej ścieżki narracyjnej stworzonej przez pisarza.

Celem niniejszych rozważań jest próba zaprezentowania możliwości interpretacyjnych powieści, skoncentrowana na relacjach zachodzących między formą i ję- 
zykiem utworu a traumą historyczną, jakiej doświadczają bohaterowie. Specyficzna konstrukcja dzieła oraz styl, który stosuje w powieści autor, przekładają się na nowatorski sposób przetworzenia historii i tematu Zagłady. Tekst odmalowuje również pejzaż polsko-ukraińskiego pogranicza wytyczanego przez historyczne, metafizyczne oraz kulturowe granice. Analizie i interpretacji zostaje poddana obecna w utworze bogata symbolika, uwypuklająca wymiar znaczącej nieobecności zgładzonej społeczności oraz wymownej luki, białego miejsca pamięci, która po nich pozostała. Ponadto w artykule wskazane zostaną związki z pojęciem karnawalizacji Michaiła Bachtina.

Pod względem gatunkowym utwór Foera nie poddaje się jednoznacznej klasyfikacji. Synkretyczna forma, którą operuje autor, zadziwia. Czytelnik ma do czynienia ze swego rodzaju rodzinną sagą pełną wątków autobiograficznych. Natchnieniem do jej napisania były dla pisarza losy przodków pochodzących z Bielska Podlaskiego, choć - jak w jednym $z$ wywiadów stwierdził sam autor - zanim powieść powstała, nie poświęcał zbyt wiele uwagi swojej żydowskości, nie zaprzątały go również rodzinne dzieje (Everything is illuminated? Jonathan Safran Foer in interview, źródło elektroniczne). W ten sposób Wszystko jest iluminacją zmienia się w wyprawę w poszukiwaniu własnej tożsamości, korzeni, które ukonstytuowały autora. Jak stwierdza Joanna Roszak, powieść opisuje życie w obecności rodzinnych śladów Zagłady (Roszak 412). Wywołuje również skojarzenia z powieścią drogi z elementami prozy przygodowej - książkowa podróż z nowego kontynentu wiedzie w głąb starego. Jonathan przyjeżdża do Lwowa, by wspólnie z odeskim przewodnikiem i tłumaczem udać się w okolice Łucka. Ich podróż obfituje w nieoczekiwane oraz komiczne sytuacje wywołane zderzeniem kultur, czego przykład stanowić może scena, w której na głębokiej ukraińskiej prowincji główny bohater usiłuje zamówić bezmięsny posiłek, co wywołuje konsternację i zdumienie miejscowej ludności. W powieści zauważalna jest pewna orientalizacja w sposobie przedstawienia Ukrainy jako kraju zacofanego, pełnego przestępczości i korupcji. Autor Wszystko jest iluminacja sięga również do formy powieści epistolarnej. Najbardziej współczesną linię fabularną utworu tworzy korespondencja pomiędzy Aleksem a Jonathanem, już po powrocie tego ostatniego do Stanów Zjednoczonych. Taki zabieg wydaje się interesujący z kilku powodów. Dzielący bohaterów dystans nie tylko odległości, ale i czasu wobec przeżytej razem podróży i prawdy, którą poznali u jej kresu, pozwala na wymianę spostrzeżeń na ten temat z pewnym opóźnieniem. Tego typu retardacja daje możliwość przeanalizowania tego, co zdarzyło się w Trachimbrodzie i Kołkach w czasie wojny, oraz zmierzenia się z nową wiedzą na temat własnej rodziny. Co więcej, bohaterowie listownie konsultują kształt powieści autorstwa Jonathana, będącej pokłosiem wspólnej podróży, tym samym czyniąc strukturę utworu jeszcze bardziej rozbudowaną i zawikłaną.

Kompozycję powieści można określić jako szkatułkową, jednak w tym wypadku przybiera ona bardziej skomplikowaną formę. W każdej części sztetlowo-rodzinnej 
sagi jedna historia płynnie przechodzi w kolejną, prowadząc do następnych perspektyw czasowych, łącząc epizody dotyczące prapraprapraprababki protagonisty Brod z przeniesieniem akcji w lata czterdzieste XX wieku, na moment przed zaślubinami dziadka Jonathana Safrana z Zosią. Jednak stworzona przez Foera kronika dziejów rodziny nie koncentruje się jedynie na doprowadzeniu akcji do punktu kulminacyjnego, jakim jest Zagłada. Każdy epizod przesycony jest komizmem sytuacyjnym i komizmem postaci, opierającym się między innymi na budowaniu dystansu wobec opisywanych zdarzeń. W sztetlowej linii fabularnej mają miejsce: domowa przemoc w małżeństwie Brod, spowodowana wypadkiem przy pracy Kołkera/Safrana, wypełnianie religijnych powinności (palenie szabasowych świec, odmawianie kadyszu) czy życie powszednie w sztetlu, toczące się swoim własnym rytmem. Brak w tym wypadku jednej osi zdarzeń, narrator konsekwentnie prowadzi kilka wątków w dwóch płaszczyznach czasowych, by w końcu z nieuporządkowanych zdarzeń stworzyć spójną całość. Taki zabieg pozwala między innymi na wielowymiarowy ogląd postaci - inna będzie recepcja w przypadku postaci Aleksandra Perczowa seniora, gdy w finale czytelnik uzmysłowi sobie okrutną prawdę.

W tym miejscu szczególne wyrazy uznania należą się tłumaczowi powieści na język polski, Michałowi Kłobukowskiemu, którego tekst wiernie oddaje nierzadko zdumiewający, przesycony ironią i komizmem charakter utworu, stanowiący jego artystyczną dominantę. Bez jego pracy nie byłoby możliwe zaproponowanie czytelnikowi polskiemu powieści $\mathrm{w}$ podobnej formie przy jednoczesnej dbałości o oddanie realiów i kręgu kulturowego, w jakim toczy się akcja. Warstwa językowa powieści jest niezmiernie złożona. W polskim przekładzie obecne są wtręty między innymi z jidysz, ukraińskiego czy angielskiego, co zdaje się niejako znajdować odzwierciedlenie $\mathrm{w}$ fabule utworu. Bohater żydowskiego pochodzenia, będący przedstawicielem kultury amerykańskiej, zostaje przeniesiony na grunt rosyjskiego obszaru językowego. Na wyróżnienie zasługuje zwłaszcza zachowanie w tekście tłumaczenia błędów popełnianych przez Aleksa, piszącego i mówiącego po angielsku. Sposób wysławiania się bohatera pełen jest kalk składniowych zapożyczonych z rosyjskiego. Roi się w nim od lapsusów czy wyrażeń, które dla rodzimego użytkownika rosyjskiego są w pełni zrozumiałe, jednak przełożone na angielski tudzież polski nie tylko tracą swój oryginalny sens, ale zyskują nowy, często komiczny wydźwięk: „Prawdę zarzekłszy, życie mam całkiem ordynarne. Jak już wzmiankowałem, działam dużo dobrych rzeczy z sobą i innymi ludźmi, ale te rzeczy są ordynarne" (Foer 8).

Przywołany wyżej przykład, będący językową hybrydą, ilustruje cechę tak znamienną dla stylu Aleksa. Mozaika języków, po którą sięga autor, nie tylko urozmaica warstwę tekstową, pozwala również na odróżnienie stylów i maniery, w której wypowiadają się poszczególni bohaterowie na równych prawach. Uzyskany w ten sposób chór głosów, swoista polifonia, sprawia, że narracja, zwłaszcza w momen- 
tach opisujących Zagładę, nie jest jednostronna. Historia opowiadana zarówno przez Augustinę, jak i Aleksa seniora zyskuje wydźwięk spowiedzi, świadkowania współwinnych, choć ich winę można jedynie określić jako tragiczną, polegającą na ocaleniu. Zmiana perspektywy pozwala ujrzeć opisywane wydarzenia w zgoła innym świetle. $W$ wypadku pogromu i Zagłady akcent zostaje przeniesiony z oczywistych ofiar żydowskiego pochodzenia, których potomkiem i przedstawicielem jako całej zbiorowości jest główny bohater, na nienaznaczonego piętnem niezmywalnej żydowskiej winy, a zarazem współodpowiedzialnego świadka, dziadka Saszy. Aleksander Perczow senior zostaje postawiony przed wyborem tragicznym - ocalić żonę oraz dziecko czy Herszla, najbliższego przyjaciela, przerażonego, rozpaczliwie błagającego o pomoc. Dopiero skonfrontowany z ostatnią ocalałą, która początkowo zaprzecza, jakoby wiedziała cokolwiek na temat Trachimbrodu, decyduje się wyznać, w jakich wydarzeniach przypadł mu udział: „To się stało ze wszystkimi, nie tkwij w błędzie. $Z$ tego, że nie byłem Żyd, jeszcze nie wynika, że akurat ze mną to się nie stało" (Foer 341). Mimo że niewskazanie Herszla nazistom, gromadzącym wszystkich Żydów w synagodze, by chwilę później ich podpalić, byłoby równoznaczne z wymordowaniem jego własnej rodziny, pod ciężarem bagażu doświadczeń bohater zaczyna obarczać się winą za niemal bratobójczą śmierć Herszla: „Zamordowałem Herszla, rzekł" (Foer 343). W tym wypadku można mówić o utracie w rozumieniu Dominicka LaCapry, związanej z traumą historyczną, jaka dotknęła bohaterów. Amerykański uczony postuluje dokonanie rozróżnienia między utratą i nieobecnością, sugerując, że pojęcia te nagminnie są ze sobą utożsamiane. Utrata w jego przekonaniu wiąże się z konkretnym wydarzeniem lub traumą historyczną, którą utrata pozostawia, a jej antonimem pozostaje zysk, nie jak w przypadku nieobecności - obecność (LaCapra 63-64).

Z kolei Katarzyna Bojarska w swoich badaniach odnotowuje, niejako w opozycji do przytoczonych powyżej spostrzeżeń LaCapry, że aby rozpoznać utratę w jego rozumieniu, trzeba najpierw zdiagnozować rzeczywisty brak, który wywołuje melancholię czy nostalgię. Badaczka proponuje zamianę pojęć utraty i nieobecności w ujęciu LaCapry (Bojarska 49-50). Jej zdaniem, w odniesieniu do polskich powojennych doświadczeń powinno się raczej mówić o zasłanianej czy też niewidocznej nieobecności aniżeli o utracie, która wcale nie musi powodować traumy. Nieobecność w tym kontekście może wywoływać poczucie triumfu czy też niechęć do żałoby (Bojarska 50-51). Badaczka, na przykładzie doświadczenia pookupacyjnego polskich wsi i miasteczek, w których nierzadko połowa mieszkańców była obywatelami polskimi żydowskiego pochodzenia, zaznacza, że aby proces żałoby, a następnie przepracowania traumy był możliwy, należy rozpoznać nieobecność jako własną stratę lub też uznać, że nigdy nie stała się ona utratą dla danej zbiorowości (za: Janion 33-34). 


\section{Historia pewnego sztetla}

Założony w 1835 roku przez carskie władze Trachimbrod, znany również jako Zofiówka - od imienia księżniczki rosyjskiej Zofii, to dziś wyludniona ukraińska wieś, oddalona o około 50 kilometrów na północny wschód od Łucka. Zamieszkiwana głównie przez ludność żydowską pochodzącą z terenów Białorusi oraz Wołynia, do wybuchu ostatniej wojny światowej znajdowała się w granicach województwa wołyńskiego II Rzeczypospolitej. Po agresji ZSRR na Polskę Zofiówka znalazła się w jego granicach. Po wkroczeniu niemieckich wojsk w sierpniu 1942 roku społeczność żydowska, licząca ponad pięć tysięcy członków, została zamordowana przez ukraińską policję pomocniczą pod wodzą SS. Podobny los spotkał okoliczne miasteczka, zaś mienie i domy pomordowanych zagrabiono i spalono (Zofiówka, źródło elektroniczne).

Sztetl na polsko-ukraińskim pograniczu istniał naprawdę. Jego historia zainspirowała Foera do uzupełnienia dziejów Sofijówki ${ }^{2}$ o utrzymany w poetyce realizmu magicznego opis. Tym samym Sofijówka stanowi przestrzeń wytyczaną zarówno przez administracyjne, jak i metafizyczne granice, będąc miejscem styku kultur żydowskiej, ukraińskiej i polskiej³.

Jednak powieściowa etymologia obu nazw jest nieco inna; zarządzone przez Rabina Wielce Poważanego głosowanie, mające wyłonić nazwę bezimiennego dotąd sztetla, kończy się groteskowym fiaskiem. Lokalny zboczeniec, szalony szlachetka Sofijówka N. samowolnie nazywa sztetl na swoją cześć. Druga, obiegowa nazwa używana przez mieszkańców ponownie wyłoniona zostaje w wyniku głosowania. Staje się nią Trachimbrod.

[...] na północ od Kołek, okraczając granicę polsko-ukraińską niby gałązka, która spadła akurat na płot, leżał sztetl Sofijówka. Nowa nazwa - ku rozpaczy tych, którzy musieli ją dźwigać - została oficjalnie i nieodwołalnie zatwierdzona. Miała towarzyszyć sztetlowi aż do jego śmierci.

2 Pod taką nazwą funkcjonuje sztetl w powieści.

3 W tym miejscu warto wspomnieć film dokumentalny Krzysztofa Kopczyńskiego Dybuk. Rzecz o wędrówce dusz, koncentrujący się wokół miejsca pamięci w Humaniu oraz rzezi, do której doszło w 1768 roku. Miasto oddalone o 500 kilometrów od interesującego nas sztetla wykazuje zaskakująco zbieżny los z historyczną oraz powieściową społecznością żydowską zamieszkującą Zofiówkę. Film wydaje się wart odnotowania z dwóch powodów. Humań jest dziś symbolem spornego miejsca pamięci. Dla pielgrzymujących do niego Żydów to miejsce święte, dla lokalnej ukraińskiej ludności pozostaje jednak metaforą walki o niepodległą Ukrainę za cenę mordu dokonanego na Żydach i Polakach. Ponadto, podobnie do powieściowej Sofijówki, której istnienie związane jest z rzeką, dla pielgrzymujących do Humania Żydów woda ma niebagatelne znaczenie. Oba miejsca przedstawiają dziś punkty na mapie pozbawione śladów zamieszkującej je żydowskiej wspólnoty, wymazane z pamięci rdzennej, za jaką się uważa, ludności ukraińskiej. 
Czas istnienia powieściowego sztetla wyznaczają konkretne ramy czasowe, które w dużej mierze są zbieżne z prawdą historyczną:

BYŁ OSIEMNASTY marca 1791 roku, kiedy ośmiokołowy wóz Trachima B. przygwoździł go albo i nie przygwoździł do dna rzeki Brod (Foer 17).

PO POŁUDNIU OSIEMNASTEGO MARCA 1942 roku, tak jak w każdym Dniu Trachima od stu pięćdziesięciu lat [...] (Foer 370).

Możemy niemal precyzyjnie zakreślić na mapie obszar, na którym znajdowała się powieściowa Sofijówka, oraz zestawić go z informacjami na temat tego sztetla. Jednak w utworze Trachimbrod stanowi swego rodzaju zamkniętą przestrzeń, mikrokosmos, którego rytm życia toczy się własnym tempem. Zakłócany jest jedynie przez zdarzenia dużej skali, takie jak obowiązkowe zmiany narzucane przez lwowski magistrat czy wojna i nadciągający front. Nie oznacza to bynajmniej, że mieszkańcy żyją $\mathrm{w}$ nieświadomości $\mathrm{w}$ zakresie niepokojących wojennych doniesień czy ulegających zaostrzeniu relacji żydowsko-ukraińskich: „Sami powinniśmy pójść do nazistów! [...]. Bo wykończą nas Ukraińcy! Słyszeliście, co zrobili we Lwowie!" (Foer 361). Zadziwia jednak bierność, niemoc czy też niechęć do podjęcia jakichkolwiek działań, mogących uratować tę społeczność w obliczu zagrożenia: „Toteż nic nie zrobiono. Nie podjęto żadnych decyzji. Nie spakowano walizek ani nie opróżniono domów. [...] Czekali aż umrą, i nie możemy mieć im tego za złe [...]" (Foer 363).

Wydarzenia ukazywane z indywidualnej perspektywy poszczególnych bohaterów, jak na przykład ma to miejsce w przypadku wojennych doniesień wplecionych w miłosne wyznania Safrana i Cyganki, tylko wzmacniają wydźwięk przekazu. W ten sposób narracja łączy najintymniejsze z wyznań z przemocą, która niebawem uniesie miliony istnień, czyniąc je jeszcze bardziej osobistymi:

Pisali do siebie liściki, jak dwoje dzieci. Mój dziadek układał swoje z wycinków gazetowych [...]. Spotkajmy sie pod drewnianym mostem, to ci pokaże rzeczy wielkie, jakich nigdy, przenigdy nie widziałaś. „Się" wziął od armii, która miała pozbawić życia jego matkę: WOJSKA NIEMIECKIE ZBLIŻAJĄ SIĘ DO SOWIECKIEJ GRANICY; „pod” - z nadciągających okrętów tejże: FLOTA NAZISTÓW POKONUJE FRANCUSKĄ POD LESACS; "aj" z ciężkiej sytuacji półwyspu, w który wpatrywali się błękitnoocy najeźdźcy: NIEMCY OTACZAJĄ KRYM [...], a każdy list był kolażem nierealnej miłości i jakże realnej wojny (Foer 324).

Nie bez znaczenia wydają się symbole, którymi w powieści operuje Foer. Uważam, że na szczególną uwagę zasługują dwa z nich, których funkcjonowanie w powieści wyjaśniam i analizuję poniżej. 
Pamięć wody, która zamiast zmywać, w tym wypadku przeciwnie, zachowuje wspomnienie o Trachimie z Brodu oraz jego śmierci, będącej zarazem zawiązaniem „sztetlowej" osi fabularnej. W ten sposób rzeka staje się, mimo płynącego nurtu, repozytorium minionego czasu, zajmując miejsce szczególne w pamięci mieszkańców sztetla. Jednak bogata symbolika tego żywiołu w wielu kulturach pozwala na jeszcze jedno odczytanie tej części powieści. Równolegle z pojmowaniem wody między innymi jako początku wszelkiego stworzenia czy też fundamentu wszechświata, symbolu narodzin, siły bądź też płodności, woda funkcjonuje również jako medium, pozwalające na przekraczanie granicy między światem żywych i umarłych. Jest rezerwuarem pamięci, w którym umieszczono ślady nieistniejącego dziś świata, zarówno $\mathrm{w}$ odniesieniu do opisywanej w powieści społeczności, jak również $\mathrm{w}$ szerszym, uniwersalnym rozumieniu zagadnienia pamięci i przemijania (Kopaliński 492-493). Z kolei w judaizmie rytualna kąpiel w mykwie jest nieodzownym elementem obrzędu, pomagającym zmyć z wierzącego winy za popełnione złe uczynki. To do rzeki, poszukując ratunku, Safran zanosi swoją żonę w zaawansowanej ciąży i szuka kryjówki w jej wezbranych wodach. Tam też próbują znaleźć schronienie pozostali mieszkańcy sztetla.

Można zatem zaryzykować stwierdzenie, iż woda funkcjonuje w powieści Foera jako tekst palimpsest, na który w miarę upływu czasu nanoszono kolejne warstwy. Zasadność tego stwierdzenia zdaje się potwierdzać obrana przez autora powieści ścieżka narracyjna. Achronologiczne zestawienie dwóch płaszczyzn czasowych, w których rozgrywa się akcja utworu, początkowo wydaje się bezzasadne. Dopiero konsekwentnie prowadzony do końca powieści zabieg, polegający na przeplataniu ze sobą oddzielnych wątków, sprawia, że czytelnik jest w stanie połączyć wszystkie nitki w jedną, spójną całość. Odczytana w ten sposób historia, uzupełniona o retrospekcje bohaterów, przeistacza się w swego rodzaju rodzinną sagę ukazaną na tle tragicznych zawirowań historii na polsko-ukraińskim pograniczu. To wokół tej niestałej przestrzeni, będącej (Kopaliński 479) źródłem śmierci i odrodzenia, ale też wiedzy i pamięci ukrytej w podświadomości, koncentruje się życie niewielkiej społeczności na granicy czasu i przestrzeni, zamieszkującej odległy zakątek na krańcach ówczesnej Rzeczypospolitej.

Równie interesujące w kontekście sposobu ukazania eksterminacji mieszkańców Trachimbrodu jawią się motyle, których obecność wydaje się nieprzypadkowa. Motyl symbolizuje lekkomyślność, nieroztropność, ale też zmartwychwstanie i nieśmiertelność (Kopaliński 253). Te znaczenia zdają się odzwierciedlać postawę mieszkańców sztetla, których zachowanie nie jest w pełni zrozumiałe dla samego narratora. Likwidacja Trachimbrodu zbiega się w czasie z lokalnym świętem, Dniem Trachima, oraz towarzyszącym mu festynem i rzeczną paradą, zmierzającą do wyłonienia Królowej Tratw. Obrazy kreślone przez Foera są bardzo plastyczne, pełne ekspresji. Kopnięcie nienarodzonego dziecka w łonie matki zbiega się z hukiem bombardowania, parada tratw przyozdobionych $w$ motyle $-\mathrm{z}$ jednoczesnym 
wkroczeniem żołnierzy: „Świętowanie, niezmącone rychłą śmiercią. Rychła śmierć, niezmącona świętowaniem" (Foer 374). Przywołany cytat w doskonały sposób wpisuje się w definicję śmiechu karnawałowego w rozumieniu Bachtina. Ambiwalencja tego zjawiska zakłada między innymi, że śmierć zapowiada narodziny, a narodziny - śmierć (Bachtin 250).

Mówiąc że śmierć „zapowiada” narodziny, nieuchronnie dopuszczamy się logizowania i nieco wypaczamy ambiwalencje „,karnawałową", bo tym samym odrywamy śmierć od narodzin, rozdzielamy je jakimś dystansem. Tymczasem w żywych obrazach karnawałowych sama śmierć jest ciężarna i wydaje płód, a jej łono matczyne okazuje się grobem. Takie właśnie obrazy tworzy ambiwalentny śmiech karnawałowy, który scala w nierozerwalną jedność szyderstwo i ekstatyczną pochwałę, hołd i obelgę (Bachtin 250).

W ten sposób narrator, spajając klamrą początek i koniec dziejów Sofijówki, łączy tragizm z komizmem i beztroską czy też lekkomyślnością mieszkańców sztetla, przydaje im kolejne cechy Bachtinowskiego karnawału. Trwający w Trachimbrodzie coroczny festyn jest wydarzeniem jednoczącym całą lokalną społeczność, zarówno przedstawicieli Żydów Strzelistych, jak i Rozlazłych oraz przybyszów z odległych miast, pragnących spróbować szczęścia w zawodach „poławiaczy Trachima”, podczas których młodzi mężczyźni nurkują w poszukiwaniu worka ze złotem, wrzuconego w rzeczne odmęty przez wybieraną raz w roku Królową Tratw. Cała ceremonia nabiera szczególnego charakteru. Piekarze na tę okazję przygotowują wyjątkowo smaczne wypieki, a sztetlowe dziewczęta ubierają się tak, jak w dzień wypadku ubrane były córki rabina. Mieszkańcy okolicznych sztetli przygotowują pięknie udekorowane tratwy, wydarzeniu towarzyszy polska i ukraińska oprawa muzyczna. W ten sposób pamięć o Trachimie B., tragicznie zmarłym, jak podejrzewa część mieszkańców sztetla, w odmętach rzeki, staje się powodem powszechnej wesołości i śmiechu, karnawałem odwracającym uwagę od spraw życia codziennego. Powaga i zaduma, które powinny towarzyszyć uroczystościom, zostają zastąpione niecierpliwym oczekiwaniem oraz krzątaniną $\mathrm{w}$ przeddzień nastąpienia festynu. $\mathrm{W}$ tym szczególnym przypadku niegroźny szaleniec Sofijówka, uznawany za miejscowego błazna, wydaje się nie być osamotniony w swej roli. Dołączają do niego pozostali mieszkańcy, którzy w obliczu doniesień o grożącym im niebezpieczeństwie zamiast opuścić sztetl, zajmują się świętowaniem. Rzeczne odmęty, z których przed stupięćdziesięcioma laty wyłoniła się Brod, odgrywają rolę miejsca wiecznego spoczynku mieszkańców sztetla, którzy szukają w wodzie schronienia. Ten sam los spotyka nowonarodzone dziecko Safrana i Zosi.

Poetyka realizmu magicznego rozumiana jest przez Tomasza Pindla jako utrzymanie utworów w konwencji realistycznej, którą cechuje ogrom szczegółów, nawiązań historycznych i geograficznych przy jednoczesnym wprowadzeniu do utworów elementów magicznych i niezwykłych. Pozwala to na utwierdzenie czytelnika 
w przekonaniu, że fabuła osadzona jest w prawdziwym świecie, w którym zawsze występuje element magiczności. Jednak, co istotne dla realizmu magicznego, obecność nadprzyrodzonego pierwiastka nie zaskakuje narratora ani jego bohaterów. Jako kolejne, bardziej szczegółowe cechy tego nurtu badacz wskazuje wątpliwość czytelnika, jak sklasyfikować zjawiska, z którymi zostaje skonfrontowany, pojawiającą się niepewność $\mathrm{w}$ obliczu zakwestionowania kategorii miejsca, tożsamości i czasu, jak również nawiązania elementów magicznych do kultury ludowej i folkloru bądź synkretyzmu religijnego (Pindel 37-39). Odwołanie do nurtu realizmu magicznego jest niewątpliwie jedną z cech omawianej powieści Foera, zaś przywołane powyżej obserwacje badacza $\mathrm{w}$ tym zakresie można z powodzeniem przełożyć na powieściowy świat Wszystko jest iluminacja.

Zjawiska nadprzyrodzone obecne są w sztetlowej linii fabularnej powieści, czego przykładem może być postać Kołkera/Safrana, żyjącego przez wiele lat z ostrzem piły, pionowo wbitym w głowę. Położenie ostrza sprawia, że bohater po śmierci zostaje pokryty brązem, by odtąd jako zegar słoneczny odmierzać czas mieszkańcom Sofijówki. Z kolei martwa ręka Safrana z fizycznego defektu urasta do rangi afrodyzjaku, zapewnia bowiem bohaterowi niesamowite powodzenie. Jak magnes działa na trachimbrodzkie kobiety bez względu na wiek czy stan cywilny, czyniąc z Safrana lokalnego uwodziciela. Podobną wymowę zyskuje niezwykłe ocalenie niemowlęcia Brod, które wypływa na powierzchnię rzeki po tym, jak wpada do niej rozpędzony wóz Trachima B. (bądź też nie), przywodząc na myśl w pewnym stopniu mit założycielski Rzymu. To tylko niektóre z powieściowych elementów magicznych, które bohaterowie przyjmują bez krztyny zdziwienia. Prymat irracjonalności, o którym wspomina Pindel (Pindel 115), zdaje się stanowić cechę organizującą sztetlową płaszczyznę fabularną. Mieszkańcy Sofijówki w swoich poczynaniach sięgają po inne, zaskakujące rozwiązania, które często okazują się słuszne, w odróżnieniu od tych dyktowanych przez rozum i zdrowy rozsądek.

Podsumowując, utwór Wszystko jest iluminacja pozwala na wszechstronne, wielopoziomowe odczytania. Wymagający czytelnik doceni powieść za misterną organizację fabuły oraz bogactwo ukrytych symboli, a także odwołania do wierzeń, folkloru, czy historii. Wyjątkowości utworu niewątpliwie dowodzi odżegnanie się od patosu oraz zręczne zestawienia tego, co niskie, z wysokim, połączenie wątków religijnych z powszednią sztetlową przaśnością, zaś poetyka realizmu magicznego oraz zabieg karnawalizacji, którymi operuje pisarz, w tym wypadku stanowią nowatorskie połączenie. Zdumiewa lekkość, z jaką autor - przedstawiciel trzeciego pokolenia ocalałych - prowadzi wszystkie linie fabularne w utworze, by w kulminacji odsłonić pozornie ukryte, wymazane i wyparte z powszechnej oraz indywidualnej pamięci, widmo Zagłady. Akcję dzieła dynamizuje kipiący wigorem, pełen gier słownych kreatywny język, oddający nieistniejącą już dziś mozaikę kultur polsko-ukraińskiego pogranicza. 


\section{BIBLIOGRAFIA}

Aarons Victoria, Berger Alan L. "Third-Generation Holocaust Representation: Trauma, History, and Memory". 2017. Web.02.04.2019. <https://www.jstor.org/stable/j.ctt22727kb.4>

Bachtin, Michaił. Problemy poetyki Dostojewskiego. Przeł. Natalia Modzelewska. Warszawa: Państwowy Instytut Wydawniczy, 1970.

Bojarska, Katarzyna. „Myślenie z wnętrza pustki: od nieobecności do utraty”. Teksty drugie 5 (2014). S. 47-63.

Dybuk. Rzecz o wędrówce dusz. Reż. Krzysztof Kopczyński. Warszawa: Eureka Media, 2015.

Erner, Guillaume. Kozioł ofiarny? Genealogia modelu wyjaśniającego antysemityzm. Przeł. Ewa Burska. Warszawa: Oficyna Naukowa, 2016. S. 142-186.

Foer, Jonathan Safran. Wszystko jest iluminacją. Przeł. Michał Kłobukowski. Warszawa: W.A.B., 2002.

Hudson, Gabe. "Everything is Interrogated". 2005. Web. 02.04.2019. <https://www.villagevoice. com/2005/03/22/everything-is-interrogated/>

Keyes, Berit Haugen. "Everything is illuminated? Jonathan Safran Foer in interview". Web. 20.12.2018. $<$ https:/ / www.threemonkeysonline.com/ everything-is-illuminated-jonathan-safran-foer-in-interview/>

Kopaliński, Władysław. Słownik symboli. Warszawa: Wiedza powszechna, 1990.

LaCapra, Dominick. „Trauma, nieobecność, utrata”. Przeł. Katarzyna Bojarska. Antologia studiów nad traumą. Red. T. Łysak. Kraków: Universitas, 2015. S. 63-65.

Pindel, Tomasz. Realizm magiczny - przewodnik (praktyczny). Kraków: Universitas, 2014.

Propst, Lisa. “ «Making One Story»? Forms of Reconciliation in Jonathan Safran Foer's «Everything Is Illuminated» and Nathan Englander's «The Ministry of Special Cases»". 2011. Web. 02.04.2019. <https://www.jstor.org/stable/23035242>

Roszak, Joanna. „Oświetlające się plany. Ciche i dalekie w Extremely Loud and Incredibly Close Jonathana Safrana Foera". Studia Litteraria et Historica 2 (2013). S. 412-422.

Sundberg, Clyne Sarah. “We need to speak more about Israel”. 2017. Web. 02.04.2019. <https://judiskkronika.se/1489-2/>

Wszystko jest iluminacja. Reż. Liev Schreiber. Burbank: Warner Independent Pictures, 2005.

"Zofiówka (Trachimbrod)". Web. 20.12.2018. <https://sztetl.org.pl/en/towns/z/1313-zofiowka-trachimbrod/99-history/138329-history-of-community> 
